\title{
AS RELAÇÕES E APRENDIZAGENS PRESENTES ENTRE OS MOVIMENTOS SOCIAIS DE TRABALHADORES DE DIFERENTES CATEGORIAS PROFISSIONAIS
}

Sabrina Zientarski de Bragança'

Clarice Zientarski

\section{RESUMO}

O artigo trata das relações presentes entre os movimentos sociais autogestionários realizados pelos professores e os movimentos sociais dos trabalhadores de outras áreas profissionais. Estabelece como período histórico o final da década de 1970, década de 1980 e início dos anos 1990 no Brasil, tendo como enfoque especial o Estado Rio Grande do Sul. Objetiva trazer elementos que permitam compreender as relações entre os movimentos sociais dos trabalhadores de diferentes categorias. Utiliza como opção metodológica a pesquisa qualitativa e, como sujeitos professores que participaram dos movimentos sociais no período em estudo. Conclui que os professores aprenderam com trabalhadores de outras categorias (metalúrgicos, servidores públicos e trabalhadores do campo) e ensinaram com suas experiências e movimentos.

Palavras-chave: Autogestão. Movimentos sociais. Aprendizagens.

1 Professora da Faculdade de Educação Universidade Federal do Ceará e consultora UNESCO. Mestre em Educação pela Universidade Federal de Santa Maria-UFSM. E-mail: sabrina educampo@hotmail.com.

2 Professora Adjunta da Universidade Federal do Ceará. Coordenadora do Grupo de Pesquisa GEPPE/UFC. Professora e pesquisadora da Pós Graduação em Educação Brasileira. Doutora em Educação pela Universidade Federal de Santa Maria-UFSM. E-mail: clarice.zientarski@ ufc.br. 


\title{
RELATIONS AND LEARNING PRESENT AMONG SOCIAL MOVEMENTS OF WORKERS FROM DIFFERENT PROFESSIONAL CATEGORIES
}

\begin{abstract}
The article deals with the present relations between the self-managed social movements made by the teachers and the social movements of workers in other professional areas. Establishes as a historical period the late 1980s and early 1990s in Brazil, with the special focus the state of Rio Grande do Sul. It aims at bringing evidence to understand the relationship between social movements of workers of different categories. Uses as a methodological option qualitative research and as subject were teachers who participated in social movements during the study period. Concludes that teachers learned from workers in other categories (metallurgical, civil servants and workers in the field) and taught from their experiences and movements.
\end{abstract}

Keywords: Self-management. Social Movements of Workers. Learning.

\section{LAS RELACIONES Y APRENDIZAJES PRESENTES ENTRE LOS MOVIMIENTOS SOCIALES DE TRABAJADORES DE DIFERENTES CATEGORÍAS PROFESIONALES}

\section{RESUMEN}

El artículo trata de las relaciones presentes entre los movimientos sociales autogestionarios realizados por los maestros y los movimientos sociales de los trabajadores de otras áreas profesionales. Establece como período histórico el final de la década de 1970, 1980 y principios de los años 1990 
en Brasil, teniendo como enfoque especial el Estado Rio Grande do Sul. Pretende traer elementos que permitan comprender la relación entre los movimientos sociales de los trabajadores de las diferentes categorías. Utiliza como opción metodológica la investigación cualitativa y, como sujetos profesores que participaron de los movimientos sociales durante el período de estudio. Concluye que los maestros aprendieron con trabajadores de otras categorías (metalurgicos, funcionarios públicos y los trabajadores del campo ) y enseñaron com sus experiencias y movimientos.

Palabras clave: Autogestión. Mmovimientos sociales. Aprendizaje.

\section{INTRODUÇÃO}

O trabalho trata sobre os movimentos sociais autogestionários realizados pelos trabalhadores ao longo da história com enfoque especial aos movimentos realizados pelos trabalhadores brasileiros durante as décadas de 1980 e início dos anos de 1990, suas relações com os movimentos realizados pelos professores brasileiros e, especialmente os professores gaúchos (mulheres e homens nascidos no Estado do Rio Grande do Sul).

A pesquisa realizada e que fundamenta este texto partiu das seguintes premissas: alguns dos movimentos realizados pelos professores gaúchos podem ser considerados como autogestionários; existiram relações entre os movimentos sociais autogestionários dos trabalhadores de diferentes categorias profissionais; os trabalhadores brasileiros de outras categorias profissionais em seus movimentos ensinaram os professores e também aprenderam com eles.

Utiliza como opção metodológica a pesquisa qualitativa referenciada no aporte teórico de algumas categorias do materialismo histórico-dialético, sendo construído através de diversos momentos: apresentação de elementos que caracterizam o objeto da pesquisa, a coleta de dados, informações, revisão bibliográfica e análise interpretativa 
de dados por ser ela a síntese das contradições do contexto na qual está inserida, pois, "[...] justamente porque o real é um todo estruturado [...] o conhecimento de fatos ou conjunto de fatos da realidade vem a ser o conhecimento do lugar que eles ocupam na totalidade do próprio real" (KOSIK, 1985, p.41).

Os sujeitos da pesquisa foram os professores ligados ao movimento social e como objeto de análise focou-se nas falas/dados levantados, a partir das entrevistas e do conhecimento empírico trazido pelos professores, a partir da qual foi realizada a produção teórica, sendo que "[...] os agentes dos movimentos sociais aqui tratados expressam uma insistente preocupação na elaboração das identidades coletivas como forma de exercício de sua autonomia" (SADER; GENTILI, 1995, p.50$51)$.

Isto significa que os educadores ouvidos na amostragem são sujeitos históricos que participaram dos movimentos, na condição de grevistas e/ou dirigentes sindicais, ou então como protagonistas no processo de articulação ou desenvolvimento de experiências autogestionárias entendendo que "[...] é o homem como sujeito histórico real, que no processo social de produção e reprodução cria a base e a superestrutura, forma a realidade social como totalidade de relações sociais, de instituições e ideias" (KOSIK, 1985, p.51).

Para tanto, a pesquisa foi realizada em cinco escolas da rede pública estadual do Rio Grande do Sul, com cinco (05) professores, sendo que dois (02) desses professores foram dirigentes sindicais nas décadas de 1980 e 1990. Todos são professores que participaram de movimentos grevistas durante a década de 1980 e destes cinco, dois (02) são professores que participaram dos projetos autogestionários desenvolvidos em suas escolas na década de 1980. A amostra é heterogênea, são homens e mulheres que atuam ou atuaram na Educação Básica. Este conjunto tem as seguintes categorias: 05 professores, todos sindicalizados, sendo 04 mulheres e 01 homem, com idade entre 49 e 60 anos de idade. 
A formação sindical é variada. Afirmam ter-se formado na prática, na "militância" nos movimentos de Igreja (Movimento de Jovens e Comunidades Eclesiais de Base), no Partido dos Trabalhadores, nos Movimentos Estudantis e no próprio Movimento dos Professores. Assinalam ainda ter-se formado em cursos de formação sindical oferecido pelos Sindicatos dos Trabalhadores em Educação, pela CUT ou pelo PT.

Luciana, a $13^{\text {a }}$ filha de um casal de agricultores residentes em Três Passos, RS, iniciou no Magistério em 1975, sendo que apenas ela e sua irmã caçula, a 14a, conseguiram estudar e por isso puderam deixar a lavoura. Luciana assumiu como professora estadual em 1979, com um contrato e logo no primeiro ano como professora estadual, participou do movimento grevista dos professores gaúchos. Durante a década de 1980, a professora trabalhou na escola pública, participou do movimento dos professores em seu município natal e assumiu a direção do $27^{\circ}$ Núcleo do Centro dos Professores do Estado do Rio Grande do Sul- CPERS com sede em Três Passos.

A história de Luciana se cruza com a de Leda, uma educadora que durante parte de sua trajetória como docente participou ativamente dos movimentos dos professores na condição de grevista. Leda, uma educadora da escola pública trabalha ainda hoje como professora de Língua Portuguesa e Literatura. Participou das greves ocorridas desde o ano em que ingressou no Magistério Público Estadual. Orgulha-se por ter participado dos movimentos. A professora Leda nasceu no interior do município de Sapucaia do Sul, onde estudou até a 4a série com turma multisseriada, transferindo-se mais tarde para uma escola do Centro. Considera-se autodidata, pois sua professora primária "estudou até a $3^{\text {a }}$ série primária".

Ana Elisa, educadora, 58 anos de idade, trabalhou em uma escola pública de Porto Alegre e em uma escola cooperativada. Tem um filho e junto com seu esposo, que é funcionário de uma empresa do ramo comercial, conseguem manter as despesas da casa, embora "com bastante dificuldade" de acordo com a fala da Ana. 
A professora nasceu eviveu sempre na Região Metropolitana de Porto Alegre. Exerceu a função de professora de História desde 1986. Já trabalhou em várias escolas estaduais e foi professora do Município de Porto Alegre, "quando o município não pagava tão bem". Deixou o município para assumir o Estado em 1996.

Carmem reside em Santa Rosa-RS, onde trabalha na escola pública e também na particular. Foi professora de Geografia e História em duas escolas públicas, e, coordenadora pedagógica de uma escola particular até 2007, quando se aposentou. Diz que era feliz quando na escola pública tinha "liberdade e autonomia para trabalhar".

A educadora participou na escola pública do projeto autogestionário desenvolvido pelo coletivo dos professores. O movimento autogestionário, segundo a professora iniciou numa calorosa discussão durante a greve do "Governo Simon" (1987-1991). "Esta greve durou 96 dias", portanto, ela fala do período em que Pedro Simon foi Governador do Estado do Rio Grande do Sul. Diz que: "[...] durante a greve, pensamos em nos articular dentro da escola para fazer um trabalho diferente. Precisávamos de algo que nos motivasse, que tirasse a gente daquela desilusão em que vivíamos". A professora continua: "O governador retirou alguns direitos conquistados, puniu os grevistas, mas, no final da greve acabou voltando atrás".

Adílpio tem 67 anos de idade, com habilitação em Matemática. Já foi diretor de escola e dirigente sindical durante anos. Adílpio nasceu em Porto Alegre, capital do Estado do Rio Grande do Sul. Casado e pai de duas filhas, exerce neste momento, a função de vereador do município de Sapucaia do Sul. Afirma ter se decidido pela política a partir do seu envolvimento com os movimentos sociais, especialmente nos movimentos dos professores. O professor foi secretário e representante do CPERS durante vários anos. Afirma que é da oposição, que sempre lutou com seus colegas para que as reivindicações dos professores fossem atendidas "[...] não apenas em relação aos nossos salários, mas também com relação à escola. Qualidade de ensino, gestão democrática e investimentos na educação eram algumas das nossas reivindicações." 
Fundamentalmente, o interesse em realizar o trabalho dizia respeito à dinâmica do movimento que envolve as dimensões da vida humana, as manifestações culturais dos colegas envolvidos, a (re) construção de conhecimentos, a troca de saberes entre educadores e outros trabalhadores que participavam como sujeitos destes processos e seus resultados para entender melhor como se deram estas relações e até que ponto foram importantes para os próprios movimentos e para a sociedade. Neste sentido, convém salientar, que ao longo dos anos 80 , os professores brasileiros em quase todo o país seguiram um percurso semelhante, pois as reivindicações eram semelhantes (BULHÕES; ABREU, 1992). Este trabalho é apenas uma contribuição neste sentido, especialmente no momento em que se vive um refluxo do movimento operário (ANTUNES,1999). Este, portanto, é o teor do presente artigo e o que será discutido a seguir.

\section{A autogestão sua definição, características e as ações realizadas pela classe trabalhadora}

A autogestão representa uma mudança nas relações sociais e também nas relações de produção, e não é nova. Ela apareceu já no século XIX com os socialistas utópicos-Owen, Fourier, Proudhon - sob a forma de uma mudança gradual e pacífica da sociedade capitalista, através da fundação de livres associações de produtores. O movimento operário, desde a Revolução Francesa de 1793, se manifestou politicamente, em sua tendência espontânea, pela autogestão. Após inicialmente terem quebrado as máquinas, os trabalhadores evoluíram para a ideia de usá-las por conta própria.

A autogestão é a negação da alienação, pois, consiste na invenção de um novo tipo de atividades livremente construídas que revolucionam o trabalho, as ferramentas e os produtos (GUILLERM; BOURDET, 1976). Os movimentos autogestionários de acordo com a definição estabelecida por Castoriadis (1983) tem o mesmo sentido de sociedade autogerida, isto é, uma sociedade que se gere, isto é, dirige a si mesma. Logo, um movimento autogestionário realizado pelos 
trabalhadores é aquele que se dirige a si mesmo e quando cada um dos trabalhadores bem como o seu coletivo se dirige a si próprio.

Desde a Comuna de Paris, a autogestão foi o traço principal da práxis da classe trabalhadora em suas manifestações e lutas por melhorias em suas condições de trabalho e de vida. A autogestão manifestou-se no campo econômico, político e social sempre que os trabalhadores apareceram como sujeitos revolucionários inconformados com a situação ou com a ordem vigente. O que moveu os movimentos autogestionários ao longo da história foi a luta contra a exploração, fosse ela praticada pelo capital privado ou pelo capitalismo de Estado (TRAGTEMBERG,1986). Estes movimentos permitiram que os trabalhadores durante as lutas fossem capazes de criar organizações igualitárias - comitês de greve, comissões de fábricas e conselhos operários.

A autogestão não é apenas a "forma política" (democracia direta) do comunismo e nem mero "método de gestão das empresas". Ela revela uma relação de produção que se generaliza e se expande para todas as outras esferas da vida social. A autogestão inverte a relação entre trabalho morto e trabalho vivo que foi instaurada pelo capitalismo e, assim, instaura o domínio do trabalho vivo sobre o trabalho morto.

A autogestão não é um processo que pode ser implantado de "cima para baixo" também não pode se dar "num passe de mágica". Para que ela atinja os resultados a que propõem é necessário que o próprio grupo decida e possa no coletivo se auto-organizar. Isto implica em envolvimento, tomada de decisões e muita reflexão. A reflexão sobre o processo de organização dos trabalhadores de vários segmentos, incluindo os educadores, passa pela realidade objetiva que os integra: em condições precarizadas e desempregados da cidade, sem-terra e sememprego do campo, explorados nas relações de trabalho capitalistas, aumento da fragmentação no interior da classe trabalhadora; "[...] precarização e terceirização da força humana que trabalha, destruição do sindicalismo de classe e sua conversão num sindicalismo dócil" (ANTUNES, 1999, p.53). 
Com isto a reivindicação pela autonomia que pontuou estes movimentos expressava os ideais de movimentos exemplares organizados pelos trabalhadores que reivindicavam uma mudança valorativa na representação política, adquirindo, como forma de participação institucional a dinâmica autogestionária.

Essas organizações realizadas pelos trabalhadores ao longo da história buscavam negar as relações verticais e a dominação capitalista. As relações que surgiram foram criadas com princípios revolucionários, indicando auto-organização e consciência social e política que aqueles trabalhadores tinham de sua prática.

\section{Trajetória dos movimentos sociais autogestionários realizados pelos trabalhadores}

As experiências históricas autogestionárias que emergiram a partir de fins do século XIX, marcaram definitivamente tanto as formas de organização dos trabalhadores quanto às conquistas obtidas. No entanto, é preciso ressaltar que o próprio termo -autogestão- é recente e foi utilizado primeiramente para designar a experiência de gestão de empresa desenvolvida na lugoslávia a partir de 1951. O termo conquistou o espaço acadêmico e sindical a partir de 1968, para designar uma nova forma de organização política, econômica e social que buscava acima de tudo a autogestão e a possibilidade de que os sujeitos envolvidos nesta organização pudessem tomar suas próprias decisões.

Este processo aparece, nos momentos decisivos da luta dos trabalhadores: na Comuna de Paris (1871), na Revolução Russa de 1917, nas revoluções alemã e húngara de 1918, na Guerra Civil Espanhola (1936-1939), no Movimento de Maio de 1968 na Europa, na revolta de Krondstad em 1917, na criação do Sindicato Solidariedade na Polônia em 1978 (TRAGTEMBERG, 1986), dentre outros e, também nas lutas dos trabalhadores brasileiros, conforme será observado na sequencia.

Os movimentos realizados foram muito importantes porque sem eles, sem estarem organizados e mobilizados os trabalhadores 
não teriam conquistado a maioria dos avanços e direitos sociais. Estas conquistas se deram muitas vezes com os acordos de greves, com o objetivo de acabar com as lutas ou como tentativa de evitá-las. Estes movimentos tiveram curta duração, pois as forças opositoras sempre se mostraram mais organizadas e fortes, conseguindo com isto desarticulálos. Apesar disso, os saberes adquiridos com os movimentos auxiliaram a classe trabalhadora no entendimento de sua situação real.

Marx e Engels (1983), ao trazerem os conhecimentos sobre o socialismo científico, possibilitaram o entendimento e o esclarecimento da ação efetiva da classe trabalhadora na Europa do século XIX. Oportunizaram também à classe trabalhadora o conhecimento sobre a real situação de exploração a que era submetida. Para Marx (1982), a história da humanidade não era senão a história da luta de classes. Caberia, portanto, à classe operária o papel histórico de transformar revolucionariamente a sociedade capitalista através da ditadura do proletariado e da supressão da propriedade privada.

Bakunin (1979) assim como outros ideólogos anarquistas, defendiam a existência de comunidades livres e autogestionárias. O movimento anarquista começou a criar as condições para a aplicação das ideias deste movimento na vida diária. A ideia da autogestão, portanto, esteve presente nos programas do movimento anarquista libertário do final do século XIX e no início do século XX. Na Rússia o movimento trotskista também defendia a autogestão, sobretudo em torno dos conselhos operários. Estes movimentos que empregaram a dinâmica autogestionária revelaram também possuir um caráter social e popular.

Os movimentos sociais populares se apresentaram e afirmaram-se em meio às transformações no mundo do trabalho. Os impactos socioeconômicos e a reestruturação produtiva transformaram objetivamente a classe trabalhadora e essas mudanças trouxeram novos desafios à sua organização política coletiva. Em grande parte, esta trajetória da classe trabalhadora foi construída a partir de ações isoladas, fragmentadas e muitas vezes descontextualizada de políticas 
oficiais dos governos, ou então à revelia destas, como forma de resistência. Os movimentos nasceram, portanto, no bojo dos conflitos e buscaram lutar por justiça social coletiva, baseando-se na vontade coletiva. Com isto pode-se dizer que geralmente a reivindicação pela autonomia que pontuou estes movimentos expressava os ideais de movimentos exemplares de trabalhadores que reivindicavam uma mudança valorativa na representação política, adquirindo, como forma de participação institucional a dinâmica autogestionária.

A autogestão como nos diz Tragtemberg (1986), não é um objetivo da sociedade capitalista, seja na forma do capitalismo privado, seja na forma livre-concorrencial, monopolista ou estatal. Ela significa que o proletariado e os assalariados, em geral, geram por si mesmos suas lutas, através das quais se conscientizam de que podem administrar a produção e criar novas formas de organização do trabalho.

A autogestão manifesta-se no campo econômico, político e social sempre que os trabalhadores aparecem como sujeitos revolucionários. A causa que moveu estes movimentos foi a luta contra a exploração, seja ela praticada pelo capital privado ou pelo capitalismo de Estado.

Os movimentos sociais dos trabalhadores brasileiros: breves palavras

No Brasil os movimentos sociais aconteceram desde que o país ainda colônia de Portugal, caracteriza-se por possuir classes sociais totalmente antagônicas: a dos dominantes e dos dominados. Os índios, os negros e mais tarde os operários representavam o grupo dominado, porém, não conformado. Esta afirmação justifica-se pelo fato de que trabalhadores reagiam de diversas formas contra a exploração e contra as precárias condições de vida e de trabalho a que eram submetidos. Mais tarde, no final do século XIX e início do século XX os trabalhadores brasileiros acabaram recebendo influências de outros trabalhadores que realizavam movimentos principalmente na Europa. Isto não significa dizer que os trabalhadores brasileiros não tivessem consciência de 
sua situação, mas, indica que grupos de imigrantes que entravam no país neste período, especialmente os anarquistas, traziam ideias que estimularam os brasileiros em suas lutas.

Os movimentos dos trabalhadores brasileiros, portanto, iniciaram junto com a colonização e permaneceram. Com o surgimento dos sindicatos eles tiveram condições de se organizar e puderam aos poucos reivindicar não individualmente, mas, no coletivo e com o apoio de sua entidade, quando esta se desatrelou do Estado e passou a assumir sua própria gestão. Este processo foi lento e gradual e caminhou par e passo com o movimento e as lutas dos trabalhadores. Assim, se a sindicalização fortaleceu os trabalhadores em seus movimentos, os movimentos sociais populares enquanto sujeitos fortaleceram sua entidade de classe e participaram de forma atuante da conquista da autonomia sindical.

O conteúdo analisado a respeito dos movimentos autogestionários brasileiros revela que foi a partir da década de 1970, que eles emergiram com mais força. Isto se deve ao fato de que a expansão capitalista:

Sustentou-se (e ainda se sustenta) num processo de superexploração do trabalho, dado pela articulação de baixos salários, uma jornada de trabalho prolongada (nos períodos de ciclo expansionista) e de fortíssima intensidade, dentro de um padrão industrial significativo para um país subordinado. Esse padrão de acumulação desenvolveu-se com muita força, especialmente ao longo das décadas de 50 e 70. (ANTUNES, 1999, p. 232).

Durante os anos 80 no Brasil este processo começou a sofrer algumas mudanças, embora o seu "modelo econômico" e seu padrão de acumulação permanecessem o mesmo, podem-se observar algumas transformações no interior dos processos produtivos e de serviços indicando que o país já caminhava rumo ao processo neoliberal, o que nos países capitalistas centrais já vinha acontecendo num ritmo bastante acentuado. 
Este processo provocou uma perda bastante significativa nos salários dos trabalhadores e as relações de trabalho revelaram um caráter de exploração bem definido, enriquecendo principalmente os grupos ligados aos grandes empresários urbanos e rurais e as multinacionais e o empobrecimento da maioria da população, que enfrentava o desemprego, o arrocho salarial, e, alta do custo de vida.

Para lutar contra esta situação os trabalhadores se organizaram, reivindicando do governo a redução do custo de vida, a melhoria das condições de trabalho e a elevação dos salários. Os trabalhadores receberam apoio de setores da Igreja, da CNBB, de organizações da sociedade civil, como a Associação Brasileira de Imprensa e a Ordem dos advogados do Brasil, que se mobilizaram para apoiar as lutas operárias e também outros movimentos, como as campanhas pela anistia e pelas eleições diretas.

Ao repudiar maciçamente o autoritarismo e lutar por melhores condições de vida, o povo brasileiro criou uma nova correlação de forças, se posicionando contra a hegemonia dos grupos dominantes e tentando organizar uma contra hegemonia (Gramsci) ou uma hegemonia da classe que até então estava sendo dominada. Com a realização da Conferência das Classes Trabalhadoras, com a criação da CUT (Central Única dos Trabalhadores) e a criação de entidades intersindicais e a Conclat (Coordenação Nacional da Classe Trabalhadora) as entidades de classe se tornaram autogeridas e fortaleceram-se.

Nesta perspectiva, os movimentos realizados pelos trabalhadores, designados como autogestionários representaram movimentos em que "[...] o proletariado e os assalariados em geral geraram por si mesmos suas lutas, através das quais se conscientizam de que podem administrar a produção e criar formas novas de organização do trabalho e de suas entidades" (TRAGTEMBERG, 1986, p.9). Isto indica que em períodos de mudança social, como o que aconteceu no Brasil no período em estudo, o trabalhador se auto-organizou pelos critérios da democracia direta, na elegibilidade e revogabilidade de seus representantes, com todo o poder concentrado na assembleia geral. 
Os movimentos sociais populares que aconteceram no Brasil no período em estudo não consistem apenas em movimentos nos quais os trabalhadores assumiram a gestão de suas empresas ou das escolas no caso dos professores, mas nos movimentos que surgiram como um indicativo da necessidade de provocar mudanças sociais.

\section{Os Movimentos sociais realizados pelos professores brasileiros}

Os professores brasileiros e especialmente os professores gaúchos, objetos e sujeitos da pesquisa, também se organizaram e realizaram suas lutas contra os governos que não atendiam às reivindicações da categoria e contra as direções e ou mantenedoras de suas escolas. Ainda, alguns trabalhadores em educação ${ }^{3}$ ou de outras áreas se organizaram em suas empresas ou escolas com o objetivo de administrá-las, ou tentando criar alternativas diante da dominação capitalista.

Estes movimentos dizem respeito a uma parcela que constitui movimentos com novos padrões de ações coletivas, que permitem falar da emergência de novos sujeitos históricos e políticos. Portanto, na representação destes movimentos a luta social aparece sob a forma de manifestações que, num dado momento, convergem, fazendo emergir um sujeito coletivo com visibilidade pública. Foi desta forma que os professores da rede pública encontraram oportunidades de posicionar-se na vida pública no final da década de 1970 e durante os anos 1980, e, embora a greve e as manifestações públicas fossem proibidas aos funcionários públicos, os professores se posicionaram e foram à luta.

Na dinâmica da movimentação e nos desdobramentos da conjuntura política deste período, em sua permanente relação com Estado, os movimentos dos professores, junto com a organização sindical adquiriram contornos ou configuração. Tinham a dialética de sua existência fundada no Estado ou nos governos municipais ou

3 Trabalhadores em educação designação estabelecida a partir do momento em que o sindicato dos professores filiou-se à CUT no final da década de 1980.

Revista Educação e Emancipação, São Luís, v. 9, n. 2, jul./dez. 2016 
estaduais, pois o seu significado se relaciona prioritariamente com a questão política na sua dimensão institucional, ou seja, no quadro das organizações formais que compõem as relações de poder na conjuntura examinada.

O conjunto das ações coletivas desenvolvidas pelos professores se caracterizou desde sua emergência, por apresentar reivindicações frente a um interlocutor básico: a instituição Contratadora - Estado ou Instituição privada de ensino. Trata-se de se opor “[...] aqueles sujeitos que detém o poder sobre o bem demandado" (GOHN, 1993, p.7). Esta era, sobretudo, representada pelo Estado, e em alguns casos específicos, na rede particular de ensino, instituições confessionais ou religiosas, ou ainda os proprietários de escolas.

Essas ações reivindicativas em sua totalidade, englobavam desde questões salariais, até a perspectiva da democratização do ensino e da gestão da escola. Além disso, examinando-se o quadro de mobilizações dos professores e suas organizações neste espaço de tempo, verifica-se, que no plano ideológico e político, elas se realizaram acenando bandeiras contra o governo militar, tanto no plano local quanto nacional, e, depois, a favor da aceleração e consolidação da transição democrática.

A movimentação dos professores gaúchos reivindicou durante a década de 1980, a necessidade da eleição de diretores, a vigência de um estatuto ou plano de carreira do magistério, o concurso público para provimento de cargos e condições salariais e de trabalho adequadas. Essas reivindicações algumas vezes foram atendidas em outras foram negadas e, geralmente conquistadas com acordos de greve, mas, na maioria das vezes, foram proteladas através da utilização de argumentos técnico-administrativo-financeiros.

Por isso, pode-se considerar, sem generalizar, que a partir do final da década de 1970, durante os anos 1980, e início dos anos 1990, a organização dos professores constituiu-se em uma força política com fôlego para estabelecer interlocução com os governos, tornando públicas 
não apenas as suas reivindicações, mas, a sua condição enquanto sujeitos coletivos, revelando-se esta condição nas tentativas de negociação para fazer valer seus direitos, mas, também para pressionar o Estado com o objetivo de assumir compromissos com a escola pública.

Durante os conflitos a greve era entendida por parte dos educadores como atividade reivindicatória capaz de romper com procedimentos institucionais contidos nos marcos do aparelho do estado. Por isso a negociação e a troca se faziam presentes no processo e revelavam interesses antagônicos. As greves constituíram-se, portanto, em espaços onde os professores vivenciaram muito além da negociação em troca de uma melhor remuneração, experiências coletivas e no plano da dimensão política, afirmação da própria entidade sindical, o reconhecimento de sua própria condição enquanto sujeitos políticos dotados de direitos e de interesses coletivos.

A partir de 1988, o magistério no Rio Grande do Sul começou a fazer um lento aprendizado no sentido de articular mobilização com negociação. Com isto aproxima-se da prática sindical do conjunto dos trabalhadores do setor privado que, além dos reajustes determinados, pela política salarial, negociam uma vez por ano em sua data-base, uma pauta de reivindicações que inclui reajuste salarial. Este momento caracterizou um aprendizado (BULHÕES; ABREU, 1992), pois os educadores aprenderam com os demais trabalhadores a sindicalização da luta do magistério, conforme salientam as autoras.

As aprendizagens adquiridas: o que dizem os sujeitos da pesquisa

Gohn (1992, p. 49-50), auxilia no entendimento da conexão entre os programas de educação popular e os movimentos sociais organizados, ao trazer alguns elementos como o do trabalho das assessorias. A autora assinala que não existe movimento social puro, isolado, formado apenas de participantes populares, de base, visto que há a presença de elementos externos ao grupo demandatário (externos no sentido de pertencerem a outra categoria social), mas "[...] existe 
uma base de coesão ideológica comum que cria laços de afinidades e objetivos únicos".

Luciana, sujeito desta pesquisa, confirma esta observação quando em sua fala relata um momento em que o sindicato dos professores através do núcleo de Três Passos/RS, integrou-se com o recém formado acampamento de trabalhadores rurais sem-terra do MST, naquela localidade, na década de 1980. Luciana afirma que:

Os professores que participavam do núcleo do CPERS de Três Passos e, especialmente seus dirigentes, grupo do qual eu também fazia parte, tiveram um importante papel na organização dos trabalhadores deste movimento, à medida que participávamos das discussões, das reuniões junto à liderança do movimento e também com os demais participantes, num processo de construção coletiva, de organização e de politização (Informação verbal).

Os grupos organizados, principalmente os vinculados à ala progressista da Igreja Católica, militaram junto aos movimentos e às populações periféricas no sentido de organizá-las para pressionar os poderes públicos. Luciana confirma: "Nós militávamos não apenas com os professores, ou com o partido (PT), mas com outros grupos organizados reivindicativos. As falas da professora deixam evidentes as relações entre grupos de militância de categorias variadas.

Leda, assinala que a sua formação política se deu a partir do momento em que começou a participar das discussões promovidas pelo grupo de jovens ligados à Igreja e que:

Eu faço questão de registrar que muito do que aprendi foi participando junto com os jovens que pertenciam ao grupo da igreja. Nós nos reuníamos para jogar, para conversar, mas também para falar sobre questões muito importantes relativas à sociedade e a política. Só para você ver, ao mesmo tempo em que falávamos sobre até onde estava indo a renovação da Igreja Católica, discutíamos 
sobre a pressão que os militares exerciam apesar de estarmos a um passo da democracia. (Informação verbal).

A afirmação de Leda encontra sustentação em Gohn (1989) quando a autora analisa os paradigmas teórico-metodológicos sobre os movimentos sociais urbanos, afirma: "[...] entendemos os movimentos sociais como processos educativos para seus participantes, quer se trate das bases, lideranças ou assessorias dos movimentos" (GOHN, 1989, p.62).

Nos movimentos sociais a educação é autoconstruída no processo e o educativo surge de diferentes formas (GOHN, 1992). Num programa de educação isto seria fácil de identificar, mas, em se tratando de movimentos sociais, de acordo com a autora, algumas fontes precisam ser consideradas, como, por exemplo, as formas:

Da aprendizagem gerada com a experiência de contato com fontes de exercício do poder. Da aprendizagem gerada pelo exercício repetido de ações rotineiras que a burocracia estatal impõe: da aprendizagem das diferenças existentes na realidade social a partir da percepção das distinções nos tratamentos que os diferentes grupos sociais recebem de suas demandas. Da aprendizagem gerada pelo contato com as assessorias contratadas ou que apoiam os movimentos: da aprendizagem da desmistificação da autoridade como sinônimo de competência, a qual seria sinônimo de conhecimento. (GOHN, 1992, p.50).

Estas fontes e formas de saber no caso dos movimentos constituem um importante instrumento das classes populares, no sentido de atingirem seus objetivos. Este saber gera mobilizações e inquietações que põem em risco o poder constituído. O saber politizado, popular, condensado em práticas políticas participativas torna-se uma ameaça as classes dominantes à medida que reivindica espaços nos aparelhos estatais através de conselhos, com caráter deliberativo. Isto 
porque o saber popular estaria invadindo o campo de construção da teia de dominação das redes de relações sociais e da vida social.

Se pensarmos desta forma, poderíamos dizer que com relação a constituírem-se como espaço educativo, tanto a escola quanto os movimentos sociais, apresentam possibilidades educativas, mesmo que na prática ainda se coloquem algumas restrições e que segundo Oliveira (2001) ainda é visível na nossa sociedade, uma tentativa de privilegiar-se a escola como espaço de educação em detrimento das possibilidades educativas dos movimentos sociais. A professora Luciana confirma ao argumentar que:

\begin{abstract}
Quando nos reuníamos, não apenas no sindicato ou nas passeatas, ou greves, mas também no sindicato dos trabalhadores rurais ou sindicato dos bancários, nós estudávamos juntos e pensávamos na possibilidade de unir forças e tornar os movimentos solidários e muito maiores. Inúmeras vezes participamos de discussões e estudos que defendiam a necessidade de juntarmos nossas forças visto que nossas reivindicações, embora específicas de cada categoria, tinham muito em comum. Outro aspecto é que fazíamos reuniões com os pais nas escolas durante as greves e ali discutíamos não apenas o movimento dos professores mas as demais questões que envolviam a classe trabalhadora. (Informação verbal).
\end{abstract}

Assim, embora a escola e os movimentos sociais eduquem de forma específica ambos têm em comum o sentido político da educação. Cabe, portanto, ressaltar o caráter educativo manifesto nestas experiências, assim como constatar os espaços das práticas sociais como lugares adequados ao desenvolvimento de uma educação crítica e emancipatória. Isto é, os Movimentos Sociais Populares e ou Autogestionários podem ser vistos como espaços de educação e construção coletiva.

Diante desta afirmação, o professor Adílpio faz uma importante observação: 
Quando se fala em participação, construção coletiva e caráter educativo, lembro de trazer algumas ideias que podem contribuir com este aprendizado. Elas me marcaram quando nós professores fizemos um grande movimento em 1985, não só no nosso Estado, mas também em outros estados brasileiros e, nós aqui em Esteio, que é onde eu trabalhava na época, tínhamos alunos cujos pais também pressionavam a empresa em que trabalhavam e eram ameaçados de demissão. Estes pais não cediam e perguntavam, porque alguns professores mesmo tendo estabilidade não aderiam ao movimento (Inforrmação verbal).

O professor continua falando e revela claramente um certo desapontamento com alguns companheiros de trabalho, embora diga que:

Os pais não entendiam o que acontecia e nós mesmos que estávamos praticamente à frente do movimento não conseguíamos entender porque não mobilizávamos toda a nossa categoria. Hoje eu entendo e percebo que isto era um processo e que com o passar do tempo adquiriu força. Embora fosse um processo lento e gradual. Assim como a aprendizagem nas aulas. ${ }^{4}$

Todavia, como bem lembra Marx e Engels (1983, p.58), “[...] os indivíduos só formam uma classe na medida em que têm que travar uma luta comum contra uma outra classe. Isto porque a manifestação de interesses comuns e a realização dos que vivem sob as mesmas condições de exploração criam a possibilidade de uma consciência de classe. Quando as classes conscientes geram um movimento social e uma organização de classe, desenvolvem uma ideologia própria de classe. Ainda, "[...] na comunidade real, os indivíduos conseguem, na, e pela sua associação, simultaneamente a sua liberdade" (MARX; ENGELS, 1983, p.58). Com isto, os autores expressam a necessidade da união entre os indivíduos, o que colocaria as condições do livre desenvolvimento e movimento dos indivíduos sob o seu controle.

4 Sobre este momento e esta situação o CPERS, distribuiu panfletos e textos aos colegas professores para que se unissem à categoria, para que pudessem como classe ter maior poder de reivindicações. 
Leda lembra emocionada quando durante a greve de 1985, os professores realizaram passeata e outros trabalhadores de categorias diferentes, demonstraram apoio e determinação, caminhando lado-alado:

Em frente ao prédio do IPE (Instituto de Previdência do Estado), recebemos apoio. Os funcionários jogavam papel picado das janelas e nos aplaudiam e o grupo acabou se juntando ao nosso grupo na caminhada. A mesma coisa aconteceu na frente da Procuradoria da Justiça. E nós gritávamos: "arroz feijão, saúde, educação..." A chuva fina que caía não acabava o calor da manifestação. $E$, quando cantávamos em coro, para todos os trabalhadores que encontrávamos na rua: "Você aí parado também é explorado." (Neste momento a professora Leda para de falar e as lágrimas escorrem de seu rosto [...]). (Informação verbal).

A fala da professora indica que a história ao longo dos anos e também o próprio movimento dos professores vem demonstrando que o professor tem um papel político a desempenhar, pois se ele tem consciência crítica da escola e de suas atribuições, pode estabelecer relações entre a escola e a sociedade e tem que se posicionar como sujeito crítico e esclarecedor, pois é membro da sociedade civil e é também um intelectual (GRAMSCI,1989). Assim, na medida em que a realidade social, econômica, política e cultural se transformam porque o processo de interações inovadoras requer novas condições sociais, surge também a necessidade de uma nova distribuição de poder e de criação de novos espaços para ir situando aspectos de conscientização e politização que, com isto estariam emergindo no ambiente escolar.

Esse processo de mudança conduziria a discussões e conflitos polêmicos dentro de uma nova realidade, cujo desfecho, ainda que imprevisível, teria que ser a modificação da sociedade. Poder-se-ia então, através do engajamento aos movimentos sociais acreditar que os professores, na luta pela escola pública, pela democracia, poderiam construir e reconstruir o seu conceito e a sua consciência de classe 
e buscar através de sua própria prática o desenvolvimento integral, a educação integral (BAKUNIN, 1979) junto com seus alunos e também a sua autonomia.

Carmem contribui com esta indicação quando afirma em sua fala:

\begin{abstract}
Quando decidimos aqui na escola realizar um projeto autogestionário foram os professores que participavam ativamente do movimento de greve os primeiros a se organizarem [...] não sei explicar direito, mas parece que o fato de este grupo estar mais unido por causa dos movimentos fez eles terem mais vontade de mudar [...] parece que o movimento dá mais coragem, talvez seja a força dos colegas, quando um segura o outro (Informação verbal).
\end{abstract}

Este processo poderia se dar a partir da interação que esse sujeito educador mantém com os movimentos sociais, irrompendo os limites da sala de aula e projetando-se para o campo da política social e educacional de concepção de sociedade dentro das potencialidades ontológicas e educativas do trabalho. Com o objetivo de aproximar as suas lutas às das demais camadas exploradas para a constituição de movimentos sociais que se confrontem com as formas de dominações econômicas, políticas e sociais próprias do sistema capitalista os professores lutaram. Este foi o propósito do grupo de professores do qual a Ana Elisa fez parte na década de 1980. Segundo a colega professora:

Nossa proposta de trabalho e de reorganização da escola exigia a participação de todos, não apenas permitia. Todos tinham que participar, opinar, tomar atitudes, isto não se referia apenas aos professores, mas também aos alunos. Hoje ainda, na escola trabalhamos como cooperativa, mas muita coisa mudou, agora não gostaria de comentar [...]. (Iformação verbal).

Assim, se a escola tem como princípio norteador a participação coletiva e a autonomia individual e coletiva, ela possibilita 
que os sujeitos humanos envolvidos no processo educativo sejam autônomos em relação ao contexto educacional. Isto faz com que não apenas os professores, mas a comunidade educativa como um todo, realizem uma comunicação dialógica, propícia à criação de estruturas metodológicas que conduzam a uma escola autônoma.

O Sindicato e sua direção foram decisivos para que as manifestações atingissem o resultado verificado. Luciana auxilia neste entendimento e é incisiva ao afirmar:

\begin{abstract}
O Sindicato ao se tornar autônomo, autogestionário demonstrou preocupação em atender as reivindicações da categoria, deixando a tutela do Estado e o peleguismo passou a ser uma condição distante da entidade. Ao assumir a administração de suas finanças, ao assumir a direção do movimento, ao dialogar com os companheiros e mostrar-se preocupado com a sua comunidade o sindicato passou a ter uma importância muito grande para toda a sociedade. (Informação verbal).
\end{abstract}

Guareschi (1996) contribui com os seus argumentos para compreensão desta relação. Para ele, todo projeto empreendido junto com grupos de uma comunidade (seja esta de qualquer classe social, religião, raça etc.) deve incluir além do diálogo e a partilha de saberes, a garantia de autonomia e autogestão das próprias comunidades. Afinal, são eles que lá vivem e que vão continuar a viver. Quem vai por um tempo, para prestar um serviço, para partilhar seu saber, não pode retirar das comunidades essa prerrogativa fundamental de liberdade e autonomia. A autogestão é o ápice de relações genuinamente democráticas, onde há participação de todos o que leva "a construção da cidadania coletiva" (Luciana, Informação verbal).

Seguindo na mesma linha das afirmações dos sujeitos desta pesquisa e também os autores que tratam da temática, podem-se indicar algumas situações que merecem reflexões a respeito dos movimentos sociais e conquistas dos educadores no Rio Grande do Sul no período em estudo: 
1) Autonomia Sindical;

2) Filiação do Sindicato dos Professores à CUT, por vontade do coletivo;

3) Eleição de Diretores das Escolas Públicas Estaduais no ano de 1986;

4) Participação e mobilização de aproximadamente $95 \%$ dos professores especialmente nos movimentos realizados entre os anos de 1985 a 1989;

5) Realização de experiências autogestionárias em algumas escolas (sendo que conseguiu-se verificar o registro destas experiências apenas em duas escolas) ${ }^{5}$;

6) Enfrentamento ao capitalismo como padrão universal de exploração social, (em suas manifestações, passeatas, movimentos reivindicatórios os educadores gaúchos manifestaram-se através de cartazes, debates, documentos entregues às comunidades contra o capitalismo);

7) Preocupação com o global e também com o que acontecia no local;

8) Direito às manifestações e greves.

Além destas conquistas, outras poderiam ser citadas. Elas mostram que muitos protagonistas das lutas e dos conflitos sociais

5 Pelos contatos que foram mantidos durante o período de realização da pesquisa, que foi de dezembro de 2006 a outubro de 2008 e que objetivava levantar as experiências desenvolvidas apenas no período que foi do final da década de 1970 e os anos 1980, com aproximadamente 100 escolas estaduais do Rio Grande do Sul (através de correspondências e contatos telefônicos), realizados com os atuais diretores das escolas, apenas duas escolas afirmaram possuir registro destes projetos autogestionários. Nestas escolas o projeto desenvolvido seguia mais ou menos este processo: pesquisa participante, problematização, estabelecimento dos eixos temáticos e das categorias que seriam trabalhadas a partir da consulta feita à comunidade educativa, discussão e socialização. Realizava-se uma pesquisa que envolvia a ação educativa dentro de uma concepção popular de ciência e de educação. Na pesquisa não se considerou o movimento realizado pelas escolas itinerantes do MST por causa do período em estudo. 
estão buscando "outras formas", não apenas antineoliberais, mas anticapitalistas e não eurocêntricas. Para tanto, apontam como desafios a elaboração democrática de referências teóricas que tenham em mente a questão da centralidade do trabalho, valores e formas de ver e sentir o homem em relação com o mundo. Isso significa que é preciso ampliar a frente cultural, enquanto movimento, política e organização, atividades básicas para a hegemonia dos subalternos. Por isso, o trabalho político de formação requer uma pedagogia libertária que seja, ao mesmo tempo, uma autopedagogia capaz de unir teoria e prática e de levar adiante a reforma intelectual e moral em diálogo com a classe que vive do trabalho.

A transformação que se busca deve enfrentar e superar os dominantes e o Estado (quando este atende apenas às elites ou à ditadura de um único partido) e fortalecer os movimentos como sujeitos e os próprios sujeitos enquanto cidadãos políticos. Esse processo tem acontecido e pulsado nas lutas do povo, sendo que temas como democracia, subjetividade e emancipação fazem parte da produção do conhecimento que as lutas estão reivindicando.

\section{Considerações finais}

No Rio Grande do Sul, a história da organização sindical acompanhou a luta dos trabalhadores de outras categorias que aconteciam a nível local e nacional. Sua história foi marcada especialmente depois de 1979, por embates e conflitos, orientando-se no sentido de fazer a categoria ser reconhecida como sujeito coletivo. Nesse processo de conquistas e derrotas, os educadores estiveram em luta por complexas ações reivindicatórias no plano das relações de trabalho e também no plano da cidadania política com os governos.

Nesta perspectiva, a movimentação dos professores incorporou concepções que marcaram o ideário político do sindicalismo da década de 80, ao tematizarem questões como: autonomia, participação, democracia de base, politização e autogestão. Ao 
questionar a natureza e as práticas assistencialistas de sua própria entidade os professores contribuíram com os trabalhadores de outras categorias.

Foi com este projeto que os professores se organizaram não apenas em sua entidade sindical. Reivindicavam a democratização das escolas através da eleição de diretores e entendiam que se a construção de uma nova ordem exigia uma escola democrática, participativa e inclusiva era preciso um diretor eleito democraticamente para atender com eficiência e com princípios democráticos esta função.

O trabalho e o movimento realizado pelos professores indicavam o seu papel como intelectuais "orgânicos de classe" no sentido dado por Antônio Gramsci, que afirmava que todo homem é filósofo, por compreender que toda a atividade humana corresponde a uma determinada concepção de mundo, e formulou hipóteses para se chegar ao que chama de "momento da crítica e da consciência". Neste sentido o autor apontava para uma construção humana capaz de criticar sua própria concepção de mundo a fim de torná-la unitária e consciente capaz de proporcionar uma elaboração crítica e consciente do que cada um de nós é. Gramsci assinalava que se é verdade que toda linguagem contém elementos de uma concepção de mundo e de uma cultura, será igualmente verdade que, a partir da linguagem de cada um, é possível julgar da maior ou menor complexidade da sua concepção de mundo (GRAMSCI, 1989).

Dessa maneira, considerando o aporte teórico dos movimentos autogestionários realizados pelos educadores e também pelos trabalhadores de outras categorias no Brasil no período em estudo, é possível afirmar que suas ações e diretrizes contribuíram para colocar em discussão a sociedade capitalista e buscavam novas formas de superação das desigualdades sociais. Com isto oportunizaram o entendimento de que em cada oprimido (FREIRE, 1985) habita um revolucionário que não se deixa dominar facilmente e que na luta colabora para que seu companheiro também deixe de ser oprimido, isto é, fortalece os laços permitindo que seu camarada também se sinta 
como revolucionário e deixe a condição de oprimido.

Fica evidente, na prática destes movimentos e na fala dos sujeitos que o seu processo de educação é popular é autogestionário e culmina por facilitar os movimentos provocando a vontade de romper com o capitalismo, ou seja, assumir sua condição de intelectual orgânico de trabalhador. É necessário observar que as ideias que permearam os movimentos se mostraram contrárias à conjuntura política da época não defendendo apenas melhores condições de trabalho, mas, a democratização política e a liberdade e o próprio direito à sindicalização e a que os sindicatos se tornassem autônomos e que assim pudessem ter um caráter educativo.

As relações que se deram entre os movimentos, nas décadas em estudo revelaram, pelas características apresentadas, que os movimentos em destaque foram reivindicatórios, contestadores e apresentaram caráter dialético e histórico. Assim, no Brasil, neste período, os movimentos sociais começam a se expressar com maior visibilidade social e passam a se denominar movimentos sociais populares, destacando-se uma disputa de valores e representações que qualificava cada campo específico de atuação. De um lado uma leitura referida ao popular, cujas bandeiras eram as da autonomia, independência e democracia direta (DOIMO, 1995) são apenas de ações-diretas. Em sua grande maioria, tais movimentos, partem de lutas de ações, como saúde e educação pública, trabalho, moradia, transporte coletivo urbano, saneamento básico, segurança pública, (condições de vida no espaço urbano) e direito de cidadania. Paulo Freire, embora não tenha tido os movimentos sociais como principal objeto de suas análises, contribuiu para o entendimento da relação entre movimentos sociais e educação. Fiori afirma que: "Paulo Freire reproduz em plano próprio a estrutura dinâmica e o método dialético do processo histórico de produção do homem" (FIORI, 1985. p. 8).

Os movimentos sociais populares, portanto, especialmente os que aconteceram no Brasil do final da década de 1970 e nos anos 1980, ao estabelecer relações com os movimentos dos educadores 
gaúchos, bem como com os demais setores da sociedade, que se mostraram preocupados com a educação para a transformação, estariam realizando um movimento em busca da construção do conhecimento a partir da criação e construção coletiva. Isto indicaria um caráter educativo e transformador, embora, tivesse que enfrentar várias dificuldades e limitações. Dentre as relações verificadas entre os movimentos sociais dos trabalhadores de outras áreas e os movimentos dos educadores, destacaram-se os momentos em que ocorreu uma interação e integração entre trabalhadores e movimentos realizados por trabalhadores de categorias diferentes. Esta interação se deu quando os professores foram apoiados por outras categorias profissionais e quando ofereceram apoio.

Além disso, quando os movimentos enquanto sujeitos contribuíram para a politização e divulgação e esclarecimento da classe trabalhadora. Também quando os trabalhadores assumiram o comando dos seus movimentos e indicaram seu encaminhamento. Outra questão que mereceu destaque diz respeito ao educador que se posiciona e ajuda os demais trabalhadores ao mesmo tempo em que é ajudado.

As relações, portanto, que se deram entre os movimentos estudados e entre os sujeitos tiveram caráter pedagógico, na medida em que conjugaram em vários momentos o propósito da humanização, afirmada por Freire (1985), a autogestão como prática libertária defendida por Bakunin (1979) com a emancipação, pensada por Marx (1982), o que confirma a premissa de que quando os movimentos têm caráter autogestionário eles estabelecem relações dialéticas em que todos ao aprender também ensinam.

\section{Referências}

ANTUNES, Ricardo. Adeus ao Trabalho? ensaios sobre as metamorfoses e a centralidade do mundo do trabalho. São Paulo: Cortez, 1999.

BAKUNIN, Mikhail. Dios y el Estado. 4. ed. Barcelona: Júcar, 1979. 
BULHÕES, Maria; ABREU, Mariza. A luta dos professores gaúchos 1979-1991: o difícil aprendizado da democracia. Porto Alegre: L\&PM, 1992.

CASTORIADIS, Cornelius. Socialismo ou barbárie: o conteúdo do socialismo. São Paulo: Brasiliense, 1983.

DOIMO, Ana Maria. A vez e a voz do popular: movimentos sociais e participação política no Brasil Pós 70. Rio de Janeiro: ANPOCS, 1995.

FREIRE, Paulo. Pedagogia do oprimido. Rio de Janeiro: Paz e Terra,1985.

FRIORI, Ernani. Prefácio à Pedagogia do Oprimido. In: FREIRE, Paulo. Pedagogia do oprimido. Rio de Janeiro: Paz e Terra, 1985.

GOHN, Maria da Glória. Movimentos sociais e educação. São Paulo: Cortez, 1989.

História dos movimentos e lutas sociais: a construção da cidadania dos brasileiros. São Paulo: Loyola, 1993.

. Teorias dos movimentos sociais: paradigmas clássicos e contemporâneos. São Paulo: Loyola, 1992.

GRAMSCl, Antonio. Os intelectuais e a organização da cultura. Tradução Carlos Nelson Coutinho. 4. ed. Rio de Janeiro: Civilização Brasileira, 1989.

GUARESCHI, Pedrinho. A ideologia: um terreno minado. São Paulo: Psicologia e Sociedade, 1996.

GUILLERM, Alain; BOURDET, Yvon. Autogestão: uma mudança radical. Tradução de Hélio Pólvora. Rio de Janeiro: Zahar,1976.

KOSIK, Karel. Dialética do Concreto. Rio de Janeiro: Paz e Terra, 1985.

MARX, Karl. Progresso técnico y desarrollo capitalista: manuscritos 1861-1868. México: Cadernos de Pasado y presente, 1982.

MARX, Karl; ENGELS, Friedrich. O manifesto comunista. Rio de Janeiro: Zahar,1983.

SADER, Emir; GENTILI, Pablo. Pós-neoliberalismo: as políticas sociais e o Estado democrático. Rio de Janeiro: Paz e Terra, 1995.

TRAGTEMBERG, Maurício. Reflexões sobre o socialismo. São Paulo: Moderna, 1986. 